\title{
Immunoglobulin Transport during Gestation in Domestic Animals and Humans-A Review
}

\author{
Jéssica Borghesi*, Lara Carolina Mario, Marcio Nogueira Rodrigues, \\ Phelipe Oliveira Favaron, Maria Angelica Miglino \\ Faculdade de Medicina Veterinária e Zootecnia da Universidade de São Paulo, São Paulo, Brasil \\ Email: ${ }^{\text {jehborghesi@hotmail.com }}$
}

Received 21 July 2014; revised 3 September 2014; accepted 15 September 2014

Copyright (C) 2014 by authors and Scientific Research Publishing Inc.

This work is licensed under the Creative Commons Attribution International License (CC BY).

http://creativecommons.org/licenses/by/4.0/

(c) (†) Open Access

\begin{abstract}
Maternal immunity is the main early defense against infectious agents in newborns. Immunoglobulin G (IgG) is indispensable for immune defense against infectious agents. IgG is transported through either the colostrum or the placenta. Immunoglobulins are antibodies, and the five different classes of these antibodies are IgG, IgA, IgM, IgD and IgE. Through their biological function of binding antigens, antibodies facilitate the removal of antigens from the body. The placenta is a temporary maternal-fetal organ, whose principal function is to allow the controlled exchange of metabolites between mother and embryo/fetus during gestation. The placenta types in different species are classified by the number of membranes separating the maternal and fetal blood circulation. Humans, lagomorphs and rodents have hemochorial placentas, which require a receptor for IgG transfer. In other animals, such as horse and pig (epitheliochorial placenta), ruminants (synepitheliochorial placenta) and carnivores (endotheliochorial placenta), antibodies are transferred via the colostrum and absorbed by passive diffusion. This review covers immunoglobulin transport in several types of placentas.
\end{abstract}

\section{Keywords}

Colostrum, Immunoglobulin, Mammalian Fetal Membranes, Placenta

\section{Introduction}

Maternal acquired immunity is the main early defense against infectious diseases in newborns [1]. Antibodies are natural proteins in the body, and their structure is thought to be safe for transfer to the fetus [2]. Thus, ma-

${ }^{*}$ Corresponding author.

How to cite this paper: Borghesi, J., et al. (2014) Immunoglobulin Transport during Gestation in Domestic Animals and Humans-A Review. Open Journal of Animal Sciences, 4, 323-336. http://dx.doi.org/10.4236/ojas.2014.45041 
ternal antibody transfer is an important mechanism for protecting newborns while their immune systems lack a humoral response [3].

Immunoglobulin G (IgG) is indispensable due to its protective roles against infectious agents. IgG may be transferred through either the colostrum or the placenta [4] [5]. Immunoglobulin transfer via the colostrum has been described in several studies. For example, Meo-Scotoni and Machado (1992) [6] and Lang et al. (2007) [5] analyzed the IgG concentration in horse colostrum, and Silper et al. (2012) [7] measured the IgG concentration in cows. Similarly, IgG transfer via the placenta in humans has been reported by Hironaka and Casanova (2003) [8] and Palmeira (2012) [3].

Bidirectional transport between the placenta and maternal blood is facilitated by the large surface area of the placental membrane. The transport of almost all substances through the placental membrane involves one of four transport mechanisms: simple diffusion, facilitated diffusion, active transport and pinocytosis [9]. Transfer across the maternal-fetal barrier depends on the thickness and extent of the barrier as well as the concentration gradient or presence of active transport mechanisms [10]-[12].

Immunoglobulins are antibodies that belong to a family of globular proteins and constitute a group of glycoproteins present in the serum and tissue fluids of all mammals. There are five classes of immunoglobulins: IgG, IgA, IgM, IgD and IgE. Each class is characterized by different sizes, electrical charges, amino acid content and carbohydrate content [13]. The biological function of antibodies is to bind antigens and thereby facilitate their removal from the body. Each antibody recognizes an epitope, a small portion of the surface of a large molecule, such as a polysaccharide or protein. To defend itself from the many existing pathogens, such as bacteria, viruses and other disease-causing agents, the body creates immunoglobulins, which recognize the antigens of $\mathrm{B}$ cells. These proteins are produced by the B cells themselves and have highly specific antigen recognition. Thus, the main function of immunoglobulins is to bind pathogenic agents and induce an immune response [14].

IgG is the main immunoglobulin in the blood system, accounting for approximately $80 \%$ of the total circulating immunoglobulin. It is also present in the tissue spaces. IgG is responsible for neutralizing viruses and bacterial toxins, facilitating phagocytosis and lysing bacteria [13]. During gestation, this immunoglobulin passes through the placenta from mother to fetus [15] [16].

The placenta can be classified by the number of membranes (layers of tissue of both maternal and fetal origin) that separate the maternal and fetal circulatory systems in the placental barrier region. This yields four types of placentas: epitheliochorial, synepitheliochorial, endotheliochorial and hemochorial [17].

Antibody transfer from mother to fetus is directly influenced by the type of placenta in a given species. In humans, lagomorphs and rodents, which have a hemochorial placenta, IgG is transported by the neonatal Fc receptor (FcRn) [18] [19]. In other animals, including horses and pigs (epitheliochorial placenta), ruminants (synepitheliochorial) and carnivores (endotheliochorial), antibodies are transported through the colostrum [20]-[22].

\section{General Background on Placentation}

Viviparous vertebrates develop a complex system of nutritional membranes surrounding the fetus during gestation. A placenta forms in all areas where there is apposition and interaction between the fetal membranes and the uterine epithelium [17]. The primary function of the placenta is to promote exchange between the mother and the developing embryo/fetus throughout gestation [23] [24]. Consistent with this function, the placenta is a highly vascularized organ that allows more or less intimate contact (depending on the species) between the maternal and fetal circulatory systems [23].

Due to the high variability in mammalian species, placentas can be classified according to several criteria, as described by Leiser and Kaufmann (1994) [17]. These criteria include the number of embryonic/fetal membranes involved and the amount of time they remain in contact with the uterus, the exterior shape of the organ, the geometric model of interdigitation between the maternal and fetal surfaces, the type and number of tissue layers separating the maternal and fetal blood supply and the geometric rearrangement of the capillaries in the maternal-fetal exchange region, all of which affect nutritional intake.

Four fetal membranes contribute to placental formation and embryonic/fetal development: the chorion, the allantois, the amnion and the yolk sac [25]. The chorion is a layer of epithelium derived from the blastocyst wall, or trophectoderm. In most species, the chorionic epithelium or trophoblast is the outermost layer of the fetal placenta and represents the definitive barrier for maternal-fetal exchange [24]. The amnion consists of three layers: a simple epithelial layer, a thick basal membrane and an avascular mesenchyme [26]. The amnion functions 
as a membranous sac that holds the conceptus in amniotic fluid, preventing its desiccation and acting as a shock absorber to protect the fetus from impacts. Together, these functions ensure that the structure of the fetus is neither distorted nor placed under pressure [27]. The amnion obtains its nutrition and oxygenation from the chorionic fluid, the amniotic fluid and the vessels on the fetal surface [28]. Yolk sac formation begins when the hypoblast (primitive endoderm) is displaced and delaminates to create the cavity of the blastula. The mesoderm in the embryonic primitive knot migrates from the epiblast and the hypoblast, transforming the blastula into a three-layer structure. The epiblast then becomes the chorionic trophoblast. The cavity lined by the endoderm is the yolk sac [29]. The endoderm-derived yolk sac gives rise to the embryonic primitive intestine. In other species, the yolk sac is locally anchored to the chorion, connecting parts of its capillary network to the fetus via yolk vessels; subsequent formation of the choriovitelline placenta occurs in Perissodactyla and carnivores. In this arrangement, the yolk vessels are more important for exchange than the yolk epithelium. In some mammals, such as rodents, the yolk sac replaces the chorion and thus forms the most external embryonic membrane (yolk sac placenta). The allantois functions as an extra-embryonic bladder and develops as a diverticulum of the caudal portion of the posterior embryonic intestine. Its surrounding mesenchyme is highly vascularized (allantoic vessels). The allantoic epithelium may surround a large vesicle or eventually rupture and regress. Accordingly, the involvement of the allantois in the trans-placental exchange process is limited [17].

One of the roles of the mammalian placenta is to facilitate nutrition during fetal development [24]. Nutrition consists of the transport of nutrients, gases and water to the fetus along with the excretion of fetal metabolic wastes into the maternal blood circulation [30]. For these exchanges to occur, the maternal and fetal circulatory systems must be tightly integrated at the placental barrier.

The term "placental barrier" refers to the tissue layers between the fetal and maternal circulatory systems [17]. The fetal components include the endothelium, mesenchyme and trophoblast, while the maternal tissues include the epithelium, uterine connective tissue and endothelium. The placenta is characterized by the number and positioning of its layers. In epitheliochorial placentas (pigs and horses), the uterine epithelium makes contact with the chorion. In synepitheliochorial placentas (ruminants), the uterine epithelium is missing, and the maternal connective tissue directly contacts the chorion. In endotheliochorial placentas (carnivores), the uterine epithelium and the connective tissue may be lacking, permitting contact of the maternal endothelial basal membrane with the chorion. Finally, hemochorial placentas (rodents, lagomorphs and humans) lack all of the maternal tissue layers, and the chorion directly contacts the maternal circulation [17].

According to Baintner (2007) [31], there are two processes by which antibodies may be transferred from mother to fetus. In humans and rodents, which have hemochorial placentas, antibodies (namely, IgG) are directly transported through the placenta. In animals with other types of placentas, antibodies are secreted in the maternal milk and subsequently absorbed by the fetus. Antibody transfer during gestation varies according to the type of placenta in each species [18]. Passive immunity acquired by the fetus through the placenta is essential for the newborn to adapt to the extra-uterine environment. Maternal antibodies transferred through the placenta protect the newborn from infection during the first few months of life [22]. For animal species in which the placenta functions as a barrier preventing antibody transfer to the fetus during gestation, immune transfer involves ingestion and absorption of colostrum [20] [32].

\section{Transfer of Immunity in Species with Epitheliochorial and Synepithelial Placental Barriers}

Horses and pigs have epitheliochorial placentae, which prevent intra-uterine passage of antibodies from mother to fetus [29] [33]. The trophoblast cells are juxtaposed with but do not invade the epithelial cells; fusion of the trophoblast cells with the uterine epithelial cells may also occur [33]. This type of placenta has six cell layers and inhibits the passage of immunoglobulins and other immunological factors to the fetus during pregnancy. Therefore, the only immunity a newborn receives from its mother derives from the colostrum [34].

The six juxtaposed tissue layers between the maternal and fetal circulatory systems that form the epitheliochorial placental barrier are as follows: maternal capillary endothelium, uterine connective tissue, uterine epithelium, chorionic epithelium, fetal connective tissue and fetal capillary endothelium. These six layers create a barrier preventing maternal antibody transfer to the fetus [4].

The synepitheliochorial barrier, which is present in cows and other ruminants, is very similar to the epitheliochorial barrier. Binucleated chorionic cells migrate to the chorionic epithelium to attach to the uterine epithelial 
cells. In a study of these binucleated cells in buffalo, progesterone receptors were found to be present throughout gestation [35]. In cows, binucleated cells also synthesize progesterone [36] [37]. The presence of progesterone receptors on both the fetal and maternal sides of the placenta throughout buffalo gestation indicates the importance of progesterone for maintaining maternal-fetal homeostasis in terms of placental differentiation, growth and regulation [35]. The corpus luteum is initially responsible for progesterone production and maintaining pregnancy, but later synthesis is performed by the placenta. Progesterone receptors have been detected in the trophoblast and caruncular epithelium during gestation in both cows [38] and buffalo [35].

As with the epitheliochorial placenta, the synepitheliochorial placenta consists of six tissue layers in the placental barrier region that prevent the passage of maternal antibodies to the fetus. Accordingly, the immune system of neonatal ruminants for defending against microorganisms is passively received through the colostrum. The synepitheliochorial placenta is a hybrid of maternal-fetal epithelium and characterized by the migration of fetal trophoblast cells (binucleated cells) into the maternal tissue. The tissue layers creating the boundary between the maternal and fetal circulatory systems are as follows: maternal capillary endothelium, maternal connective tissue, maternal epithelium, trophoblasts, embryonic connective tissue and fetal endothelium [17] [39] [40].

The term "colostrum" refers to the first lactic secretion, which occurs as a result of offspring birth. This milk is enriched with elements of the blood serum, including immunoglobulins (primarily IgG). The secretion occurs for a short time, and the antibody levels gradually decrease over time, with very low levels observed 24 hours after birth [41] [42]. Antibodies in the colostrum are absorbed via pinocytosis by epithelial cells in the small intestine, particularly in the jejunum and ilium. Immunoglobulins are transported to the local lymphatic tissue and subsequently enter the circulatory system through the thoracic duct, thereby providing immunity to the newborn [43].

As previously reported by Lang et al. (2007) [5] and Meo-Scotoni and Machado Neto (1992) [6], the amount of IgG in the colostrum and in the offspring's serum may vary among different breeds, but IgG consistently represents the most prevalent immunoglobulin, regardless of breed.

Horses and pigs have an epitheliochorial placenta that prevents intra-uterine passage of maternal antibodies to the fetus. Passive immunity transfer therefore occurs through the ingestion and absorption of the colostrum, which provides protection against microorganismal infection after birth [4] [44]-[46]. Meo-Scotoni and Machado Neto (1992) [6] and Koterba et al. (1990) [4] have ascribed the yellowish color and viscosity of colostrum to the presence of IgG, with higher viscosity and coloring indicative of higher IgG concentrations in the milk. Total protein can also be used to estimate IgG concentration. The majority of the immunoglobulins in the colostrum originate from the mother's blood rather than the mammary glands [47].

According to Rouse and Ingran (1970) [48], the concentration of IgG in the maternal serum is two times lower than that in the colostrum before the offspring's first breastfeeding. The same authors also showed that immunoglobulin concentrations in the colostrum, particularly that of IgG, greatly decrease over time. Therefore, the offspring must ingest the colostrum during the first two hours of life; six hours after birth, immunoglobulins are detectable in the offspring's serum, indicating immunity in the body [4]. In addition to high concentrations of IgG, the immunoglobulins IgM and IgA are also present in the colostrum at lower quantities [49].

Cattle have a synepitheliochorial placenta, which corresponds to direct contact of the chorionic epithelium with the uterine tissues and prevention of maternal immunity via the placenta. Although this placenta protects the fetus against most microorganisms, its prevention of the passage of serum proteins such as immunoglobulins results in inadequate immunity of the calf at birth. Thus, newborn calves depend on antibodies from the colostrum [7] [50]. The colostrum of cattle has high immunoglobulin levels, and IgG is the most abundant class [51].

Colostrum-derived immunity is the most common form of protection for calves and other ruminants because immunoglobulins are not transferred during gestation in these species [52]. A study performed by Pires-Junior unpublished (2009) [53] showed that calves do not have immunoglobulins in their bodies prior to colostrum ingestion and that immunoglobulin levels increase shortly after the secretion is ingested, reaching maximal levels after 12 to 48 hours (Figure 1(a) and Figure 1(b)).

\section{Immunity Transfer in Species with Endotheliochorial Placental Barriers}

The endotheliochorial placenta type is present in carnivores, such as cats and dogs [54] [55], and consists of six 


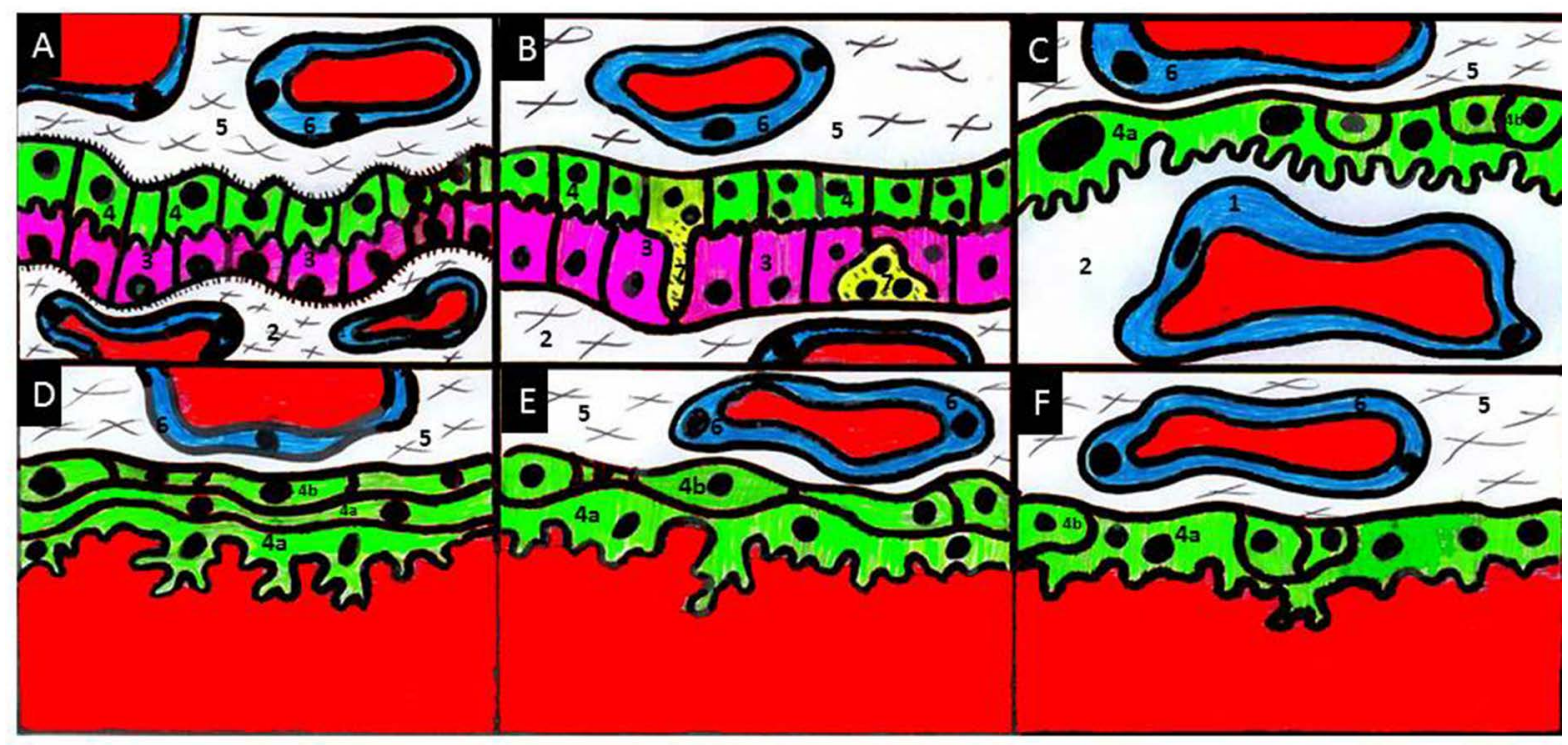

Figure 1. Types of the placental barrier: [A] epitieliochorial, [B] synepitheliochorial, [C] endotheliochorial, [D] hemotrichorial, [E] hemodichorial and [F] hemomonochorial. Components of the placental barrier: In (1) maternal endothelium, (2) maternal connective tissues, (3) uterine epithelium, (4) trophoblasts, (4a) syncytiotrophoblast, (4b) cytotrophoblast, (5) fetal connective tissues, (6) fetal endothelium and (7) trophoblast giant cell.

tissue layers between the maternal and fetal blood systems [56]. Blood flow from the mother to the fetus is characterized as a simple flow or a simple cross flow [54] [55].

In dogs, immunoglobulins from the mother are passed to the fetus via the placenta during the last trimester of gestation in a specific placental region with a hemochorial organization and via the colostrum provided by the mammary gland [57]. Immune transfer via the colostrum is consistent with the placenta in carnivores being mostly endotheliochorial in character, which prevents immunoglobulin transfer. The placenta type is the most important determinant of the mode of immunoglobulin transfer to the fetus. Thus, in dogs, only $5 \%$ to $10 \%$ of immunoglobulins are transferred through the endotheliochorial placenta from mother to offspring. The same processes occur in other carnivorous species, including felines [57] and coatis of the Procyonidae family, such as Nasua nasua [58]. These species also have specialized regions of the placenta, such as the auxiliary structure called the hemophagous zone, which may facilitate the transport of substances and minerals such as iron.

The endotheliochorial placenta in carnivores is characterized by the formation of a zonal track or belt around the circumference of the uterine lumen [59]. The placenta consists of four layers separating the maternal and fetal circulatory systems: The endothelium of the maternal uterine vasculature, the chorion, the fetal mesenchyme and the fetal endothelium [17]. In this type of placenta, the cells of the trophoblast are moderately invasive; the cells of the cytotrophoblast and syncytiotrophoblast layers break down the maternal epithelium without destroying the endothelial portion then remain in close contact with the fetal tissues [17].

Maternal-fetal circulation is simple and has countercurrent flow. It follows a single path, and the fetal blood flow is almost horizontal [17].

Another important characteristic of the placenta in carnivores is the presence of placental hematomas, or more specifically, hemophagous zones, regions where maternal blood elements are phagocytized by fetal cells. This phenomenon occurs in the lateral margins of the chorioallantoic placenta. Maternal blood is extravasated from the interglandular capillaries into the space between the endometrium and chorioallantois [60].

Ambrósio (2004) [54] reported that hematoma regions in carnivores contain streams of extravasated blood between the placental tissue and the endometrial glands that function as a hematoma liquid communication base at approximately 35 days of gestation. Covering the entire placental belt in a uterine-fetal orientation are the maternal arteries. Their caliber decreases as they approach the fetal surface, forming an arterial-venous capillary bed in a lamellar arrangement. The pattern remains the same until the vessels form the primary contact villi or maternal-fetal exchange zones.

According to Stoffel et al. (2000) [57], IgG transfer occurs among all of the layers of the maternal-fetal bar- 
rier in the labyrinth zone. After analyzing the maternal vessels in the labyrinth zone, the authors observed that IgG was unequally distributed in the tissue. It is important to reiterate, however, that in carnivores, most immunoglobulins are transferred from mother to fetus via the colostrum [59] (Figure 1(C)).

\section{Transfer of Immunity in Species with Hemochorial Placental Barriers}

During hemochorial placentation, the maternal tissue is invaded and destroyed by trophoblasts. Consequently, the chorionic surface directly contacts the maternal circulation [61] [62]. The three layers separating the maternal and embryonic circulation are the trophoblast layer, the embryonic connective tissue and the embryonic capillary endothelium [17]. Enders (1965) [61] classified hemochorial placentas according to the number of trophoblast layers present, resulting in the following groups: hemomonochorial (one trophoblast layer, Figure 1(D)), hemodichorial (two trophoblast layers, Figure 2(E)) and hemotrichorial (three trophoblast layers, Figure 2(F)). Hemomonochorial placentas are found in some monkeys [63], rodents of the suborder Hystricomorpha [64]-[69] and humans at the end of gestation [70]. Hemodichorial placentas are found in lagomorphs [61] and in humans during early gestation [70]. Finally, hemotrichorial placentas are found in murine rodents [61] and Cricetidae [71].

Comparing the different placenta types, transfer is reportedly easiest in hemochorial placentas [72]. Of the five classes of antibodies, IgA, IgD, IgE, IgG and IgM, only IgG can be transferred from mother to fetus through the placenta. There are four IgG subclasses: IgG1, IgG2, IgG3 and IgG4 [72].

Immunoglobulins are hydrophilic molecules with a molecular weight of approximately $150 \mathrm{kD}$ and cannot be transported by simple diffusion. Instead, their movement across the placental barrier requires active transport and the specific action of a receptor [73] (Figure 2). The implicated receptor is the Fc receptor (FcR), which is specific to the Fc portion of IgG. The Fc region of these antibodies interacts with immune system cells, and the antibodies themselves may be present on the surface of phagocytic cells and some lymphocytes. In this way, the antibody binds an antigen and is taken up by a phagocytic cell, ultimately ensuring that the bound antigen is enveloped by the phagocytic cell. FcRs are also important for the transmission of cell surface signals into the cell. This function requires the aggregation of FcRs on the cell surface by antibodies or multivalent antigens. There are unique Fc receptors for each class of antibody: FcyR binds IgG, Fc $\varepsilon$ R binds IgE, Fc $\alpha$ R binds IgA, Fc $\mu$ R binds IgM, and Fc $\delta$ R binds IgD. Furthermore, there are three major "classic" Fcy receptors: FcyRI, FcyRII and FcyRIII. FcyRI (CD64) is a high affinity receptor expressed mainly on macrophages, while FcyRIII (CD16) is a low affinity receptor found on mononuclear phagocytes, granulocytes, platelets and NK cells. FcyRII (CD32) is a low affinity receptor present on B cells, mononuclear phagocytes, granulocytes and platelets [70] [74]-[76]. In addition to the Fc $\gamma$ Rs, the placenta may also express the neonatal Fc receptor (FcRn), which has been observed in human placental tissue [19], specifically in the syncytiotrophoblast membranes and in the fetal capillary endothelium [77] [78]. The syncytiotrophoblast and the fetal capillary endothelium have also specifically been shown to act as cell barriers that regulate IgG transport across the placenta [79].

The syncytiotrophoblast is the first barrier against maternal-fetal IgG transfer but can be crossed via binding with a specific receptor [80], namely, FcRn [81]. IgG transport across the placenta is an active, selective and intracellular process specifically mediated by FcRn. In rodents and humans, the Fc region of maternal IgG binds the FcRn receptor under acidic conditions to cross the epithelial cells and is liberated at physiological pH [81] [82]. During gestation, maternal IgG is transferred by the placental syncytiotrophoblast, a layer supplied by maternal blood, and internalized in endosomes. In rodents, this transport mechanism is particularly important during breastfeeding, and FcRn receptors are expressed by the epithelial cells of neonatal intestine. This expression begins during fetal development, peaks neonatally and falls significantly after weaning [81] [83]. In humans, on the other hand, the receptors are involved in the placental transfer of maternal IgG from fetal development and into adulthood [77] [84] [85].

The fetal capillary endothelium is the second placental barrier, but its function is not well known. FcRn is expressed only at low levels in the fetal veins, indicating the involvement of another transport mechanism in this placental layer [73]. Because endothelial cells closely contact each other, it is assumed that IgG crosses intracellularly rather than paracellularly between the endothelial cells. Furthermore, IgG moves passively via caveolar transcytosis [73].

FcRn receptors have been shown to be present in the human placenta during the first 12 weeks of gestation [82]. Active IgG transport through the placenta begins early and increases proportionally until the end of gesta- 


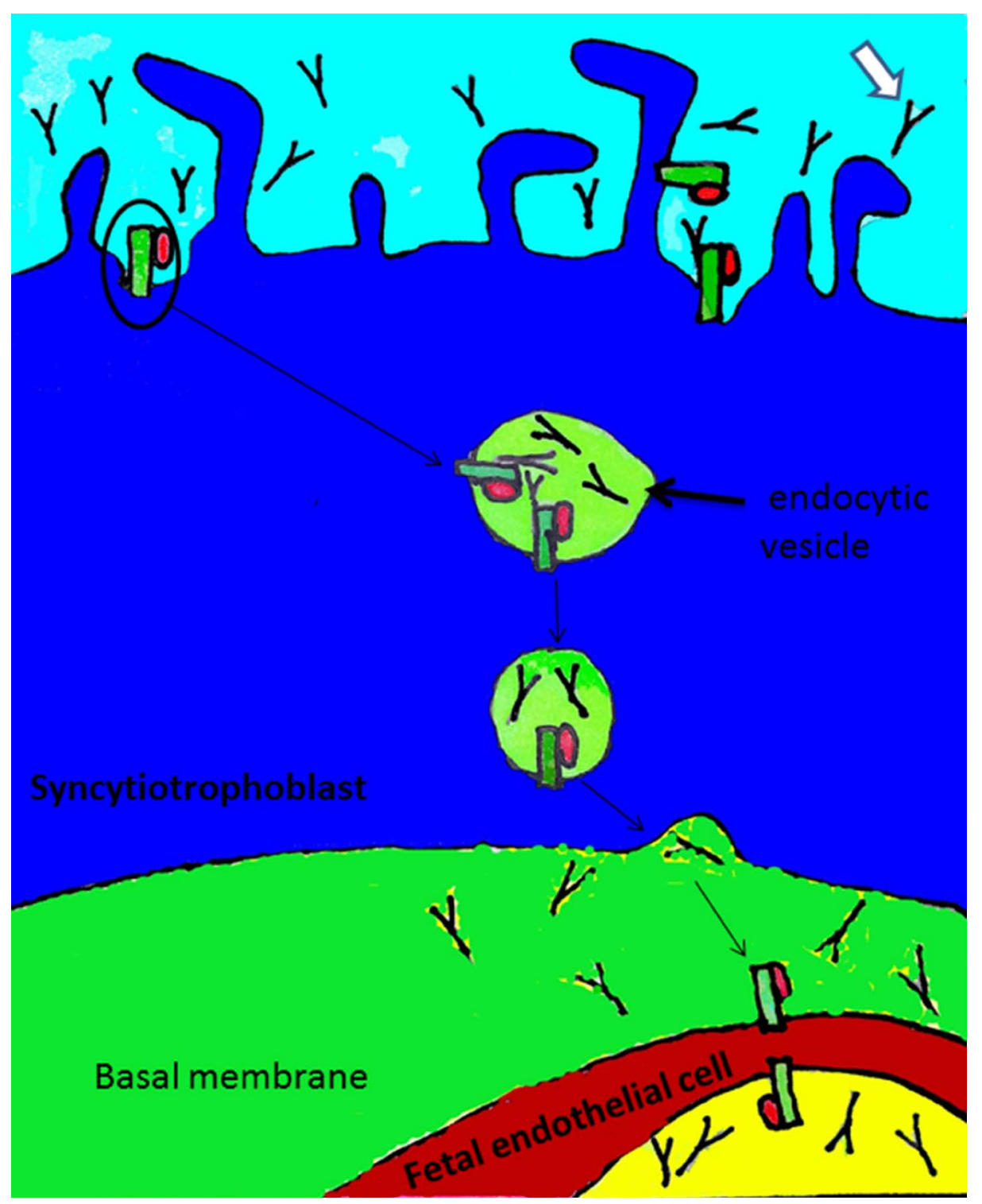

Figure 2. Schematic view of immunoglobulin transport across the maternal-fetal barrier in the placenta. The IgG (white arrow) present in maternal blood, bind to specific receptors (halo) present on the surface of syncytiotrofoblast cells, then occur the transport of these molecules to the receptors present in the fetal blood.

tion. Gestational age influences total IgG levels in the umbilical cord, as evidenced by a linear correlation between these parameters. At approximately 32 weeks of gestation, the detectable antibody levels in newborns are approximately $400 \mathrm{mg} / \mathrm{dl}$ and can reach values higher than $1000 \mathrm{mg} / \mathrm{dl}$ at term, at times exceeding the maternal levels [86] [87].

Studies have shown that IgG transport occurs in decreasing order for the IgG1, IgG4, IgG3 and IgG2 subclasses [72]. The concentration of IgG in the fetus originates from the mother, reflecting maternal transport [88]. Currently, it is known that the newborn receives a humoral immunity provided by the mother's placental transfer selective immunoglobulin G (IgG). This transport occurs in the third trimester of pregnancy and is started in syncytiotrophoblast through endocytosis mediated by specific membrane receptors [89]. Fetal IgG begins around the second trimester of gestation, and between 8 and 10 weeks was already a very low level in the villous stroma of the placenta and begins to increase from 13 to 18 weeks of gestation, where the fetus is about $10 \%$ of the maternal concentration. The greatest increase in total IgG levels is observed between 22 and 26 weeks of gestation, where the fetus will present about 50\% of maternal concentration [90]-[92]. Total fetal IgG concentration con- 
tinues to increase during the final trimester and typically exceeds the maternal IgG concentration at term. The rate of increase between 29 and 41 weeks is about twice the rate observed between 17 and 28 weeks of gestation [92] [93]. IgG1 represents most of the excess total IgG in fetal circulation at term. IgG1, IgG3 and IgG4 levels all increase exponentially during pregnancy. There is general consensus that the IgG1 subclass is transported most efficiently, followed by IgG4, IgG3 and finally IgG2, which exhibits the lowest transport levels. Fetal IgG3 and IgG4 levels are similar to those in the maternal circulation during this period. IgG2 levels, however, slowly increase in a linear fashion during gestation and remain significantly lower (up to 60\%) than the IgG2 concentration in the maternal blood. Fetal IgG2 levels are three times lower than IgG1 levels between 17 and 22 weeks of gestation and seven times lower between 37 and 41 weeks of gestation [92] [93].

In contrast to humans, where most maternal IgG is transferred to the fetus during pregnancy in utero, IgG is mainly transmitted postnatally in rats. Most of the transmission occurs after birth and continues throughout most of the lactation period [83]. Additionally, FcRn expression in the intestine persists throughout the neonatal period until weaning. Maternal antibody levels in rats are detectable at approximately 17 days of gestation, increase rapidly after 2 days then remain relatively constant at the maternal concentration until (or past) breastfeeding [94].

As in rodents, prenatal antibody transfer in the rabbit yolk sac is well-studied. Three distinct periods of yolk sac function have been observed in rabbit. During the initial period (until 8 days of gestation), antibodies are transferred via the uterine lumen and the nonvascularized bilaminar membrane of the yolk sac. During the second period (from 8 to 13 days of gestation), the yolk sac partially inverts, and antibody transfer is minimal. In the final period (from 13 to 32 days of gestation), the yolk sac endoderm is in close contact with the uterine epithelium, allowing more efficient transport [95] [96]. In contrast to the observations in other species, IgM class antibodies in rabbit are transported through the placenta at significant levels and transported to the fetal blood through the yolk sac splanchnopleura [31] [97].

In this sense, an important clinical point worth mentioning relates to inflammatory bowel disease, which is a disease that predominantly affects women during the reproductive period, especially between 15 and 35 years old. It is a chronic inflammatory process and idiopathic, whose major clinical forms are Crohn's disease and ulcerative colitis [98] [99]. Disease activity at conception has been associated with premature births, low birth weight, and fetal loss [100]-[102]. One of the main problems is the use of medications that are potentially teratogenic to the fetus, often leading to improper suspension of drugs needed for maintenance of remission of inflammatory bowel disease [103]. Although considered high-risk pregnancy, the rate of complications of pregnancy in a patient with this disease is under control, the patient does not differ much from the general population [104]. Infliximab a chimeric monoclonal antibody that acts against tumor necrosis factor $\alpha$, is indicated for the induction treatment and maintenance of remission in patients with moderate to severe disease activity [105] [106]. Infliximab has a large molecular structure is not possible it crosses the placenta during early pregnancy [107]. However, recent studies have shown detectable serum levels of infliximab in children up to about six months of childbirth [103]. Being composed of a IgG1 antibody, probably crosses the placental barrier more easily from the third quarter [108]. Thus, its use is indicated up to 30 weeks of gestation [109]. Adalimumab is another monoclonal antibody to recombinant human immunoglobulin (IgG1) containing only human peptide sequences, specific against tumor necrosis factor. Presents the same information in disease that infliximab, as well as those who have lost response to infliximab [106] [110]. Most literature data on its use in pregnancy is based on case reports [111], where no increased incidence of malformations or other complications were observed. Available on its passage through the placenta information is scarce, since its levels can not yet be measured commercially.

\section{Immunity Transfer through the Yolk Sac}

Immunoglobulins can also be transported through the yolk sac, which is the first membrane formed (even before the main placenta forms) to promote maternal-fetal exchange.

In most rodents, the yolk sac inverts along with the main placenta to form the yolk sac placenta [112]. The yolk sac placenta, or inverted yolk sac, is composed of two layers: an inner layer consisting of vascularized fetal mesenchyme and an outer layer of endodermic epithelium. This type of placenta occurs in both rodents and lagomorphs [17] [96]. The yolk sac placenta is structurally diverse among rodent species, and little is known about the processes driving maternal-fetal exchange via the yolk sac [113]. Nevertheless, the yolk sac placenta plays 
important roles in embryo/fetus development before and after chorioallantoic placenta formation [90] [114].

In many species, it is likely that a wide range of nutrients can be transferred from mother to fetus through the visceral yolk sac [115]. In rodents, the yolk sac is the major nourishing organ in the embryo prior to the formation of the functional allantoic placenta. In mouse, the yolk sac forms and, as in voles, completely surrounds the amnion through most of gestation [116]. In many rodents and lagomorphs, the yolk sac is actively involved in embryonic and fetal nutrition [115], the yolk sac persists during the fetal period in these species.

Although endodermal cells in the yolk sac are not particularly selective in terms of absorbing macromolecules, they are selective in terms of which macromolecules are transported to the fetus [115]. Immunoglobulin transfer is one case in point [117]. Thus, selective protein transport is an important function of the yolk sac. Moreover, protein degradation by the yolk sac also plays an important role in fetal nutrition [115], as previously discussed.

The FcRn receptor is found in the endoderm of the fetal yolk sac, where immunoglobulins are transported from mother to fetus during gestation. Similar to IgG transport in the human syncytiotrophoblast, IgG transport across the fetal yolk sac involves the FcRn receptor and its $\mathrm{pH}$-dependent binding activity. IgG binds to the receptor in the acidic environment of the endosome, followed by dissociation of the complex and release into the blood [118].

\section{Conclusions}

We conclude from this review that IgG is the only immunoglobulin class that can be transferred to the fetus during gestation. Moreover, only the hemochorial placenta is capable of transporting immunoglobulins during gestation. For other placenta types, immunity is transferred to the neonate via the colostrum. IgG transfer increases beginning in the third trimester of gestation and is mediated by FCRn receptors along with the IgG-specific receptor FcyRI. The yolk sac placenta, which inverts in rodents and partially inverts in lagomorphs, represents the major nourishing organ during embryonic development. In these species, IgG is transferred by the same receptor found in humans-FcRn.

Knowledge of the characteristics of the maternal fetal placental transport, is of fundamental importance within the medical area, mainly to perinatal medicine, which provides the exploitation and manipulation of these mechanisms in benefits to the newborn.

The study of the mechanism of transplacental immunoglobulin, offer numerous advantages for developing healthier and safer for the fetus. Thus the problems of malformation in fetal growth can be tested through toxicity test that assess factors that affect fetal harm training. Therefore knowledge study involving transplancetario cooperate to transport the improvement of embryo development and no new perpesctiva treatment of immunodeficient diseases.

\section{Acknowledgements}

We would like to thank the Brazilian Federal Agency for the Support and Evaluation of Graduate Education (Coordenação de Aperfeiçoamento de Pessoal de Nível Superior-CAPES) and the Research Foundation of the State of Sao Paulo (FAPESP) for the financial support for this study.

\section{References}

[1] Madani, G. and Heiner, D.C. (1988) Antibody Transmission from Mother to Fetus. Current Opinion in Immunology, 11, 1157-1164. http://dx.doi.org/10.1016/0952-7915(89)90009-5

[2] Englund, J., Vicari, M. and Dode, B. (2003) Protection of New Born through Maternal Immunization (Preface). Vaccine, 21, 3351.

[3] Palmeira, P., Quinello, C., Silveira-Lessa, A.L., Zago, C.A. and Carneiro-Sampaio, A. (2012) IgG Placental Transfer in Healthy and Pathologica Pregnancies. Clinical and Developmental Immunology, 2012, 1-13.

[4] Koterba, A.M., Drumond, W.H. and Kosch, P.C. (1990) Equine Clinical Neonatology. Lea \& Febiger, Philadelphia, 846.

[5] Lang, A., Souza, M.V., Salcedo, J.H.P., Sossai, S., Araújo, R.R., Lourenço, G.G. and Leandro, M. (2007) Imunidade passiva em eqüinos: Comparação entre a concentração de IgG do soro materno, colostro e soro do neonato. Bibliotheca Anatomica, 54, 405-411.

[6] Meo-Scotoni, C.M. and Machado Neto, R. (1992) Transferência de imunidade passiva em equinos: Características imunológicas do processo de formação do colostro. Revista Brasileira de Zootecnia, 21, 200-204. 
[7] Silper, B.F., Coelho, S.G., Madeira, M.M.F., Ruas, J.R.M., Lana, A.M.Q., Reis, R.B. and Saturnino, H.M. (2012) Avaliação da qualidade do colostro e transferência de imunidade. Arquivo Brasileiro de Medicina Veterinária e Zootecnia, 64, 281-285. http://dx.doi.org/10.1590/S0102-09352012000200005

[8] Hironaka, H.C. and Casanova, L.B. (2003) Concentrações séricas de imunoglobulinas em sangue do funículo umbilical e em sangue materno no momento do parto. Acta Cirúrgica Brasileira, 18, 159-166. http://dx.doi.org/10.1590/S0102-86502003000200013

[9] Moore, K. and Persaud, T.V.N. (2008) Embriologia Básica. Elsevier, São Paulo.

[10] Rosso, P. (1981) Nutrition and Maternal-Fetal Exchange. The American Journal of Clinical Nutrition, 34, 744-755.

[11] Jones, H.N., Powell, T.L. and Jansson, T. (2007) Regulation of Placental Nutrient Transport: A Review. Placenta, 28, 763-774. http://dx.doi.org/10.1016/j.placenta.2007.05.002

[12] Donnelly, L. and Campling, G. (2008) Functions of the Placenta. Anaesthesia and Intensive Care Medicine, 9, $124-127$. http://dx.doi.org/10.1016/j.mpaic.2010.11.001

[13] Atkinson, D.E., Boyd, R.D.H. and Sibley, C.P. (2006) Placental Transfer. Elsevier, Manchester.

[14] Janeway, C.A., Travers, P., Walport, M. and Shlomchik, M. (2002) Imunobiologia: O sistema imune na saúde e na doença. Artmed, Porto Alegre.

[15] Down, J.A., Michiko, K., Klein, M.H. and Dorrington, K.J. (1989) Proteins Associated with Activity of Fc Receptors on Isolated Human Placental Syncytiotrophoblast Microvillus Plasma Membranes. Placenta, 10, 27-46. http://dx.doi.org/10.1016/0143-4004(89)90025-8

[16] Johnston, P.M. and Brown, P.J. (1981) Fc Receptors in the Human Placenta. Placenta, 2, 355-370. http://dx.doi.org/10.1016/S0143-4004(81)80031-8

[17] Leiser, R. and Kaufmann, P. (1994) Placental Structure: In a Comparative Aspect. Experimental and Clinical Endocrinology, 102, 122-134. http://dx.doi.org/10.1055/s-0029-1211275

[18] Marques, R.S., Vulcano, M., Cazerta, S.M.M., Miglino, M.A., Neto, A.C.A. and Pereira, F.T.V. (2007) Caracterização morfológica da região intercaruncular de vacas e búfalas gestantes. Biotemas, 20, 103-114.

[19] Story, C.M., Mikulska, J.E. and Simister, N.E. (1994) A Major Histocompatibility Class I-Like Fc Receptor Cloned from Human Placenta: Possible Role in Transfer of Immunoglobulin G from Mother to Fetus. The Journal of Experimental Medicine, 180, 2377-2381. http://dx.doi.org/10.1084/jem.180.6.2377

[20] Giguère, S. and Polkes, A.C. (2005) Immunologic Disorders in Neonatal Foals. The Veterinary Clinics of North America: Equine Practice, 21, 241-272. http://dx.doi.org/10.1016/j.cveq.2005.04.004

[21] Crisman, M.V. and Scarratt, W.K. (2008) Immunodeficiency Disorders in Horses. The Veterinary Clinics of North America: Equine Practice, 24, 299-310. http://dx.doi.org/10.1016/j.cveq.2008.03.003

[22] Tizard, I.R. (2009) Immunity in the Fetus and Newborn. In: Veterinary Immunology: An Introduction, Elsevier, St. Louis, 221-233.

[23] Gudmundsson, S., Dubiel, M. and Sladkevicius, P. (2009) Placental Morphologic and Functional Imaging in High-Risk Pregnancies. Seminars in Perinatology, 33, 270-280. http://dx.doi.org/10.1053/j.semperi.2009.04.005

[24] Riquelme, G. (2009) Placental Chloride Channels: A Review. Placenta, 30, 659-669. http://dx.doi.org/10.1016/j.placenta.2009.06.002

[25] Wolf, E., Arnold, G.J., Beier, H.M., Einspainer, R., Frohlich, T., Hiendleder, S., Kolles, S., Prelle, K., Reinchenbach, H.D., Stojkovic, M., Wenigerkind, H. and Sinowatz, F. (2003) Embryo-Maternal Communication in Bovine-Strategies for Deciphering a Complex Cross-Talk. Reproduction in Domestic Animals, 38, 276-289. http://dx.doi.org/10.1046/j.1439-0531.2003.00435.x

[26] Benirschke, K. and Kaufman, P. (2000) Pathology of the Human Placenta. Springer-Verlag, New York. http://dx.doi.org/10.1007/978-1-4757-4199-5

[27] Okazaki, T., Casey, M.L., Okita, J.R., Macdonald, P.C. and Johnston, J.M. (1981) Initiation of Human Parturition XII. Biosynthesis and Metabolism of Prostaglandins in Human Fetal Membranes and Uterine Decidua. American Journal of Obstetrics and Gynecology, 139, 373-381.

[28] Toda, A., Okabe, M., Yoshida, T. and Nikaido, T. (2007) The Potential of Amniotic Membrane/Amnion-Derived Cells for Regeneration of Various Tissues. Journal of Pharmacological Sciences, 105, 215-228. http://dx.doi.org/10.1254/jphs.CR0070034

[29] Mossman, H.W. (1987) Vertebrate Fetal Membranes. Rutgers University Press, New Brunswick.

[30] Cetin, I. and Alvino, G. (2009) Intrauterine Growth Restriction: Implications for Placental Metabolism and Transport. A Review. Placenta, 23, S77-S82. http://dx.doi.org/10.1016/j.placenta.2008.12.006

[31] Baintner, K. (2007) Transmission of Antibodies from Mother to Young: Evolutionary Strategies in a Proteolytic Envi- 
ronment. Veterinary Immunology Immunopathology, 117, 153-161. http://dx.doi.org/10.1016/j.vetimm.2007.03.001

[32] Crisman, M.V. and Scarratt, W.K. (2008) Immuno Deficiency Disorders in Horses. The Veterinary Clinics of North America: Equine Practice, 24, 299-310. http://dx.doi.org/10.1016/j.cveq.2008.03.003

[33] Moffett, A. and Loke, C. (2006) Immunology of Placentation in Eutherian Mammals. Nature, 6, 584-594. http://dx.doi.org/10.1038/nri1897

[34] Acworth, N.R.J. (2003) The Healthy Neonatal Foal: Routine Examinations and Preventative Medicine. Equine Veterinary Education, 15, 207-211.

[35] Carvalho, A.C, Mançanares, C.A.F., Pereira, F.T.V., Ambrósio, C.E. and Miglino, M.A. (2007) Imunolocalização de receptores de progesterona nas células trofoblásticas binucleadas na placenta de búfalo (Bubalus bubalis). Biotemas, 20 , 99-106.

[36] Reimers, T.J., Ullman, M.B. and Hansel, W. (1985) Progesterone and Prostanoid Production by Bovine Binucleate Trophoblast Cells. Biology of Reproduction, 33, 1227-1236. http://dx.doi.org/10.1095/biolreprod33.5.1227

[37] Ullman, M.B. and Reimers, T.J. (1989) Progesterone Production by Binucleate Trophoblastic Cells of Cows. Reproduction, 37, 173-179.

[38] Shuler, G., Wirth, C., Klisch, K., Pfarrer, C., Leiser, R. and Hoffmann, B. (1999) Immuno Localization of Progesterone Receptors in Bovine Placentomes throughout Mid and Late Gestation and Parturition. Biology of Reproduction, 61, 797801. http://dx.doi.org/10.1095/biolreprod61.3.797

[39] Wooding, F.B.P. (1992) The Synepitheliochorial Placenta of Ruminants: Binucleate Cell Fusions and Hormone Production. Placenta, 13, 101-113. http://dx.doi.org/10.1016/0143-4004(92)90025-O

[40] Enders, A.C. and Blankenship, T.N. (1999) Comparative Placental Structure. Advanced Drug Delivery Reviews, 38, 315. http://dx.doi.org/10.1016/S0169-409X(99)00003-4

[41] Bessi, R., Pauletti, P., d’Arce, R.D. and Machado Neto, R. (2002) Absorção de anticorpos do colostro em bezerros. I. Estudo no intestino delgado proximal. Revista Brasileira de Zootecnia, 31, 2314-2324. http://dx.doi.org/10.1590/S1516-35982002000900021

[42] Tizard, I.R. (2002) Imunologia veterinária. Roca, São Paulo.

[43] Riddle, W.T. (2003) Preparation of the Mare for Normal Parturition. Proceedings of the 49th Annual Convention of the American Association of Equine Practitioners, AAEP, New Orleans, 1-5.

[44] Salmon, H. (1999) The Mammary Gland and Neonate Mucosal Immunity. Veterinary Immunology and Immunopathology, 72, 143-155. http://dx.doi.org/10.1016/S0165-2427(99)00127-0

[45] Rooke, J.A. and Bland, I.M. (2002) The Acquisition of Passive Immunity in the New-Born Piglet. Livestock Production Science, 78, 13-23. http://dx.doi.org/10.1016/S0301-6226(02)00182-3

[46] Ullrey, D.E., Struthers, D.G. and Hendricks, B.E. (1966) Composition of Mare’s Milk. Journal of Animal Science, 25, 211-222.

[47] Portter, P. (1979) Adoptive Immunization of Neonate by Breast Factores. In: Ogra, P.L. and Dayton, D., Eds., Immunology of Breast Milk, Raven Press, Raven, 197-206.

[48] Rouse, B.T. and Ingram, D.G. (1970) The Total Protein and Immnoglobulin Profile of Equine Colostrum and Milk. Immunology, 19, 901-907.

[49] Rumbaugh, G.E., Ardans, A.A. and Ginno, D. (1979) Identification and Treatment of Colostrum-Deficient Foals. Journal of American Veterinary Medical Association, 174, 273-276.

[50] Tizard, I.R. (2000) Veterinary Immunology. Saunders Company, Philadelphia.

[51] Stott, G.H. (1980) Immunoglobulin Absorption in Calf. Journal of Dairy Science, 63, 681-688. http://dx.doi.org/10.3168/jds.S0022-0302(80)82990-0

[52] Robson, J.D., Stott, G.H. and Denise, S.K. (1988) Effects of Passive Immunity on Growth and Survival in the Heifer. Journal of Dairy Science Association, 71, 1283-1287. http://dx.doi.org/10.3168/jds.S0022-0302(88)79684-8

[53] Pires Junior, J.B. (2009) Evaluation of Passive Transfer of Immunity in Newborn Calves Derived from Dystocia Obtained by Caesarian Section. Dissertation, Universidade Rural de Pernambuco, Recife.

[54] Ambrósio, C.E., Miglino, M.A., Lima, A.R., Martins, D.S., Assis-Neto, A.C., BonatelI, M., Verechia, F.T. and Carvalho, A.F. (2004) Fissura placentária de gatos SRD, Felis catus-Linnaeus, 1758. Aspectos macro e microscópicos. Brazilian Journal of Veterinary Research and Animal Science, 41, 81-85. http://dx.doi.org/10.1590/S1413-95962004000200001

[55] Miglino, M.A., Ambrósio, C.E., Martins, D.S., Wenceslau, C.V., Pfarrer, C. and Leiser, R. (2006) The Carnivore Pregnancy: The Development of the Embryo and Fetal Membranes. Theriogenology, 66, 1699-1702.

http://dx.doi.org/10.1016/j.theriogenology.2006.02.027 
[56] Furukawa, S., Kuroda, Y. and Sugiyama, A. (2014) A Comparison of the Histological Structure of the Placenta in Experimental Animals. Journal of Toxicology Pathology, 27, 11-18. http://dx.doi.org/10.1293/tox.2013-0060

[57] Stoffel, M.H., Fries, A.E. and Hartman, S.H. (2000) Ultrastructural Evidence of Transplacental Transport of Immunoglobulin G in Bitches. Journal of Reproduction and Fertility, 118, 315-326. http://dx.doi.org/10.1530/jrf.0.1180315

[58] Favaron, P.O., Morini Junior, J.C., Mess, A.M., Miglino, M.A. and Ambrósio, C.E. (2014) Placentation and Fetal Membrane Development in the South American Coati Nasua nasua (Mammalia, Carnivora, Procyonidae). Reproduction Biology and Endocrinology, 12, 57. http://dx.doi.org/10.1186/1477-7827-12-57

[59] Johnston, S.D., Kristriz, M.V. and Ollson, P.N.S. (2011) Canine and Feline Theriogenology. Elsevier Health Sciences, New York.

[60] Amoroso, E.C. (1952) Alanto-Chorionic Differentiations in the Carnivora. Journal of Anatomy, 86, 481-482.

[61] Enders, A.C. (1965) A Comparative Study of the Fine Structure in Several Hemochorial Placentas. American Journal of Anatomy, 118, 29-67. http://dx.doi.org/10.1002/aja.1001160103

[62] Trundley, A. and Moffett, A. (2004) Human Uterine Leukocytes and Pregnancy. Tissue Antigens, 63, 1-12. http://dx.doi.org/10.1111/j.1399-0039.2004.00170.x

[63] Ramsey, E.M. (1982) The Placenta—Human and Animal. Praeger Publishers, CBS Educational and Professional Publishing, New York.

[64] Flamini, M.A., Portiansky, E.L., Favaron, P.O., Martins, D.S., Ambrósio, C.E., Mess, A.M., Miglino, M.A. and Barbeito, C.G. (2011) Chorioallantoic and Yolk Sac Placentation in the Plains Viscacha (Lagostomus maximus): A Caviomorph Rodent with Natural Polyovulation. Placenta, 32, 963-968. http://dx.doi.org/10.1016/j.placenta.2011.09.002

[65] Oliveira, M.F., Vale, A.M., Favaron, P.O., Vasconceles, G.B., Oliveira, G.B. and Miglino, M.A. (2012) Development of Yolk Sac Inversion in Galea spixii and Cavia porcellus (Rodentia, Caviidae). Placenta, 33, 878-881. http://dx.doi.org/10.1016/j.placenta.2012.06.019

[66] Oliveira, M.F., Mess, A., Ambrósio, C.E., Dantas, C.A.G., Favaron, P.O. and Miglino, M.A. (2008) Chorioallantoic Placentation in Galea spixii (Rodentia, Caviomorpha, Caviidae). Reproductive Biology and Endocrinology, 6, 39. http://dx.doi.org/10.1186/1477-7827-6-39

[67] Miglino, M.A., Franciolli, A.L.R., Oliveira, M.F., Ambrósio, C.E., Bonatelli, M., Machado, M.R.F. and Mess, A. (2008) Development of the Inverted Visceral Yolk Sac in Three Species of Caviids (Rodentia, Caviomorpha, Caviidae). Placenta, 29, 748-752. http://dx.doi.org/10.1016/j.placenta.2008.05.007

[68] Bonatelli, M., Carter, A.M., Lima, M.C. and Miglino, M.A. (2005) Placentation in the Paca (Agouti paca L). Reproductive Biology and Endocrinology, 3, 9. http://dx.doi.org/10.1186/1477-7827-3-9

[69] Kanashiro, C., Santos, T.C., Miglino, M.A., Mess, A.M. and Carter, A.M. (2009) Growth and Development of the Placenta in the Capybara (Hydrochaeris hydrochaeris). Reproductive Biology and Endocrinology, 7, 57. http://dx.doi.org/10.1186/1477-7827-7-57

[70] Boyd, J.D. and Hamilton, W.J. (1970) The Human Placenta. Heffer \& Sons, Cambridge.

[71] Favaron, P.O., Carter, A.M., Ambrósio, C.E., Morini, A.C., Mess, A.M., Oliveira, M.F. and Miglino, M.A. (2011) Placentation in Sigmodontinae: A Rodent Taxon Native to South America. Reproductive Biology and Endocrinology, 9, 55. http://dx.doi.org/10.1186/1477-7827-9-55

[72] Kane, S.V. and Acquah, L.A. (2009) Placental Transport of Immunoglobulins: A Clinical Review for Gastroenterologists Who Prescribe Therapeutic Monoclonal Antibody Estowomen during Conception and Pregnancy. American Journal of Gastroenterology, 104, 228-233. http://dx.doi.org/10.1038/ajg.2008.71

[73] Saji, F., Samejima, Y., Kamiura, S. and Koyama, M. (1999) Dynamics of Immunoglobulins at the Feto-Maternal Interface. Reviews of Reproduction, 4, 81-89. http://dx.doi.org/10.1530/ror.0.0040081

[74] Lotteau, V., Teyton, L., Peleraux, A., Nilsson, T., Karlsson, L., Schmid, S.L., Quaranta, V. and Peterson, P.A. (1990) Intracellular Transport of Class MHCII Molecules Directed by Invariant Chain. Nature, 348, 600-605. http://dx.doi.org/10.1038/348600a0

[75] Saji, F., Koyama, M. and Matsuzaki, N. (1994) Human Placental Fc Receptors. Placenta, 15, 453-466. http://dx.doi.org/10.1016/S0143-4004(05)80415-1

[76] Simister, N.E. and Story, C.M. (1997) Human Placental Fc Receptors and the Transmission of Antibodies from Mother to Fetus. Journal of Reproductive Immunology, 37, 1-23. http://dx.doi.org/10.1016/S0165-0378(97)00068-5

[77] Leach, J.L., Sedmak, D.D., Osborne, J.M., Rahill, B., Lairmore, M.D. and Anderson, C.L. (1996) Isolation from Human Placenta of the IgG Transporter, FcRn and Localization to the Syncytiotrophoblast. The Journal of Immunology, 157, 3317-3322.

[78] Simister, N.E., Story, C.M., Chen, H.L. and Hunt, J.S. (1996) An IgG Transporting Fc Receptor Expressed in the 
Syncytiotrophoblast of Human Placenta. Europian Journal of Immunology, 26 ,1527-1531. http://dx.doi.org/10.1002/eji.1830260718

[79] Takizawa, T., Anderson, C.L. and Robinson, J.M. (2005) A Novel Fc- $\gamma$ R-Defined, IgG-Containing Organelle in Placental Endothelium. Journal of Immunology, 175, 2331-2339. http://dx.doi.org/10.4049/jimmunol.175.4.2331

[80] Malek, A. (2003) Ex Vivo Human Placenta Models: Transport of Immunoglobulin G and Its Subclasses. Vaccine, 21, 3362-3364. http://dx.doi.org/10.1016/S0264-410X(03)00333-5

[81] Roopenian, D. and Akilesh, S. (2007) FcRN: the Neonatal Fc Receptor Comes of Age. Nature Reviews Immunology, 7, 715-725. http://dx.doi.org/10.1038/nri2155

[82] Englund, J.A. (2007) The Influence of Maternal Imunization on Infant Imune Response. Journal of Comparative Pathology, 137, 16-19. http://dx.doi.org/10.1016/j.jcpa.2007.04.006

[83] Baker, K., Qiao, S.W., Kuo, T., Kobayashi, K., Yoshida, M., Lencer, W.I. and Blumberg, R.S. (2009) Immune and Non-Immune Functions of the (Not So) Neonatal Fc Receptor, FcRn. Seminars in Immunopathology, 31, 223-236. http://dx.doi.org/10.1007/s00281-009-0160-9

[84] Israel, E.J., Taylor, S., Wu, Z., Mizoguchi, E., Blumberg, R.S., Bhan, A. and Simisterne, N.E. (1997) Expression of the neonatal Fc Receptor, FcRn, on Human Intestinal Epithelial Cells. Immunology, 92, 69-74. http://dx.doi.org/10.1046/j.1365-2567.1997.00326.x

[85] Shah, U., Dickinson, B.L., Blumberg, R.S., Simister, N.E., Lencer, W.I. and Walker, W.A. (2003) Distribution of the IgG Fc Receptor, FcRn, in the Human Fetal Intestine. Pediatric Research, 53, 295-301. http://dx.doi.org/10.1203/00006450-200302000-00015

[86] Fujimura, M.D. (1991) Serum Levels of Immunoglobulin G Subclasses in Normal and Nephrotic Children. Ph.D. Dissertation, Universidade de Sao Paulo, Sao Paulo.

[87] Schelonka, R.L. and Infante, A.F. (1998) Neonatal Immunology. Seminars in Perinatology, 22, 2-14. http://dx.doi.org/10.1016/S0146-0005(98)80003-7

[88] Smister, N. (2003) Placental Transport of Immunoglobulin G. Vaccine, 21, 3365-3369. http://dx.doi.org/10.1016/S0264-410X(03)00334-7

[89] Audus, K.L. (1999) Controlling Drug Delivery across the Placenta. European Journal of Pharmaceutical Sciences, 8, 161-165. http://dx.doi.org/10.1016/S0928-0987(99)00031-7

[90] Gitlin, D. and Boesman, M. (1966) Serum Alpha-Fetoprotein, Albumin and Gamma-Globulin in the Human Conceptus. The Journal of Clinical Investigation, 45, 1826-1838. http://dx.doi.org/10.1172/JCI105486

[91] Gitlin, D. and Biasucci, A. (1969) Development of the $\gamma \mathrm{G}, \gamma \mathrm{A}, \gamma \mathrm{M}, \beta \mathrm{IC} / \beta \mathrm{IA}, \mathrm{C}$ 'l Esterase Inhibitor, Ceruloplasmin, Transferrin, Hemopexin, Haptoglobin, Fibrinogen, Plasminogen, $\alpha 1$-Antitrypsin, Orosomucoid, $\beta$-Lipoprotein, $\alpha 2-$ Macroglobulin and Prealbumin in the Human Conceptus. The Journal of Clinical Investigation, 48, 1433-1446. http://dx.doi.org/10.1172/JCI106109

[92] Malek, A., Sager, R., Kuhn, P., Nicolaides, K.H. and Schneider, H. (1996) Evolution of Maternofetal Transport of Immunoglobulins during Human Pregnancy. American Journal of Reproductive Immunology, 36, 248-255. http://dx.doi.org/10.1111/j.1600-0897.1996.tb00172.x

[93] Garty, Z., Ludomirsky, A., Danon, Y.L., Peter, J.B. and Douglas, S.D. (1994) Placental Transfer of Immunoglobulin G Subclasses. Clinical and Diagnostic Laboratory Immunology, 1, 667-669.

[94] Halliday, R. (1955) The Absorption of Antibodies from Immune Sera by the Gut of the Young Rat. Proceedings of the Royal Society of London, Series B, Biological Sciences, 143, 408-413. http://dx.doi.org/10.1098/rspb.1955.0020

[95] Brambell, F.W.R., Hemmings, W.A., Henderson, M., Parry, H.J. and Rowlands, W.T. (1949) The Route of Antibodies Passing from the Maternal to the Foetal Circulation in Rabbits. Proceedings of the Royal Society of London, Series B, Biological Sciences, 136, 131-144. http://dx.doi.org/10.1098/rspb.1949.0010

[96] Carney, E.W., Scialli, A.R., Watso, R.E. and DeSesso, J.M. (2004) Mechanisms Regulating Toxicant Disposition to the Embryo during Early Pregnancy: An Interspecies Comparison. Births Defects Research (Part C), 72, 345-360. http://dx.doi.org/10.1002/bdrc.20027

[97] Merad, Z. and Wild, A.E. (1992) The Route of Maternal IgM Transport to the Rabbit Fetus. Placenta, 13, $291-304$. http://dx.doi.org/10.1016/0143-4004(92)90044-T

[98] Mahadevan, U. (2010) Pregnancy and Inflammatory Bowel Disease. Gastroenterology Clinics of North America, 94, 53-73. http://dx.doi.org/10.1016/j.gtc.2009.07.006

[99] Smink, M., Lotgering, F.K., Albers, L. and Jong, D.J. (2011) Effect of Childbirth on the Course of Crohn's Disease; Results from a Retrospective Cohort Study in the Netherlands. BMC Gastroenteroly, 11, 2-7. http://dx.doi.org/10.1186/1471-230X-11-6

[100] Nielsen, O.H., Andreasson, B., Bondesen, S., Jacobsen, O. and Jarnum, S. (1984) Pregnancy in Crohn’s Disease. Scan- 
dinavian Journal of Gastroenterology, 19, 724-732.

[101] Morales, M., Berney, T., Jenny, A., Morel, P. and Extermann, P. (2000) Crohn’s Disease as a Risk Factor for the Outcome of Pregnancy. Hepato-Gastroenterology, 47, 1595-1598.

[102] Bush, M.C., Patel, S., Lapinski, R.H. and Stone, J.L. (2004) Perinatal Outcomes in Inflammatory Bowel Disease. Journal of Maternal-Fetal and Neonatal Medicine, 15, 237-241. http://dx.doi.org/10.1080/14767050410001668662

[103] Correia, L.M., Bonilha, D.Q., Ramos, J.D., Ambrogini, O. and Miszputen, S.J. (2010) Inflammatory Bowel Disease and Pregnancy: Report of Two Cases Treated with Infliximab and a Review of the Literature. European Journal of Gastroenterology \& Hepatology, 22, 1260-1264. http://dx.doi.org/10.1097/MEG.0b013e328329543a

[104] Habal, F.M. and Ravindran, N.C. (2008) Management of Inflammatory Bowel Disease in the Pregnant Patient. World Journal of Gastroenterology, 14,1326-1332. http://dx.doi.org/10.3748/wjg.14.1326

[105] Steinlauf, A.F. and Present, D.H. (2004) Medical Management of the Pregnant Patient with Inflammatory Bowel Disease. Gastroenterology Clinics of North America, 33, 361-385. http://dx.doi.org/10.1016/j.gtc.2004.02.013

[106] Lichtenstein, G.R., Hanauer, S.B. and Dandborn, W.J. (2009) Practice Parameters Committee of American College of Gastroenterology. Management of Crohn's Disease in Adults. American Journal of Gastroenterology, 104, 465-483. http://dx.doi.org/10.1038/ajg.2008.168

[107] Vasiliauskas, E.D., Church, J.A. and Silverman, N. (2006) Case Report: Evidence for Transplacental Transfer of Maternally Administered Infliximab to the Newborn. Clinical Gastroenterology and Hepatology: The Official Clinical Practice. Journal of the American Gastroenterological Association, 4, 1255-1258. http://dx.doi.org/10.1016/j.cgh.2006.07.018

[108] Gisbert, J.P. (2010) Safety of Immune Modul Ators and Biologics for the Treatment of Inflammatory Bowel Disease during Pregnancy and Breast-Feeding. Inflammatory Bowel Diseases, 16, 881-895. http://dx.doi.org/10.1002/ibd.21154

[109] Katz, J.A., Antoni, C., Keenan, G.F., Smith, D.E., Jacobs, S.J. and Lichtenstein, G.R. (2004) Outcome of Pregnancy in Women Receiving Infliximab for the Treatment of Crohn's Disease and Rheumatoid Arthritis. American Journal of Gastroenterology, 99, 2385-2392. http://dx.doi.org/10.1111/j.1572-0241.2004.30186.x

[110] Schnitzler, F., Fidder, H., Ferrante, M., Ballet, V., Noman, M., Assche, G.V., Spitz, B., Hoffman, I., Steen, K.V., Vermeire, S. and Rutgeerts, P. (2011) Outcome of Pregnancy in Women with Inflammatory Bowel Disease Treated with Antitumor Necrosis Factor Therapy. Inflammatory Bowel Diseases, 17, 1846-1854. http://dx.doi.org/10.1002/ibd.21583

[111] Moffatt, D.C. and Bernstein, C.N. (2007) Drug Therapy for Inflammatory Bowel Disease in Pregnancy and the Puerperium. Best Practice \& Research Clinical Gastroenterology, 21, 835-847. http://dx.doi.org/10.1016/j.bpg.2007.05.002

[112] Conceição, R.A., Ambrósio, C.E., Martins, D.S., Carvalho, A.F., Franciolli, A.L.R., Machado, M.R.F., Oliveira, M.F. and Miglino, M.A. (2008) Morphological Aspects of Yolk Sac from Rodents of Hystricomorpha Subordem: Paca (Agouti paca) and Agouti (Dasyprocta aguti). Pesquisa Veterinária Brasileira, 28, 253-259.

[113] Chan, S.T.H. and Wong, P.Y.D. (1978) Evidence of Active Sodium Transport in the Visceral Yolk Sac of the Rat in Vitro. The Journal of Physiology, 279, 385-394.

[114] King, B.F. and Enders, A.C. (1970) The Fine Structure of the Guinea Pig Yolk Sac Placenta. American Journal of Anatomy, 127, 397-413. http://dx.doi.org/10.1002/aja.1001270405

[115] King, B.F. (1982) Comparative Anatomy of the Placental Barrier. Bibliotheca Anatomica (Karger, Brasil), 22, 13-28.

[116] Renfree, M.B., Hensleigh, H.C. and Laren, A. (1975) Development Changes in the Composition and Amount of Mouse Fetal Fluids. Journal of Embryology \& Experimental Morphology, 33, 435-446.

[117] Brambell, F.W.R. (1958) The Passive Immunity in Young Mammals. Biological Reviews, 33, 488-531. http://dx.doi.org/10.1111/j.1469-185X.1958.tb01412.x

[118] Roberts, D.M., Guenthert, M. and Rodewald, R. (1990) Isolation and Characterization of the Fc Receptor from the Fetal Yolk Sac of the Rat. Journal of Cell Biology, 111, 1867-1876. http://dx.doi.org/10.1083/jcb.111.5.1867 
Scientific Research Publishing (SCIRP) is one of the largest Open Access journal publishers. It is currently publishing more than 200 open access, online, peer-reviewed journals covering a wide range of academic disciplines. SCIRP serves the worldwide academic communities and contributes to the progress and application of science with its publication.

Other selected journals from SCIRP are listed as below. Submit your manuscript to us via either submit@scirp.org or Online Submission Portal.
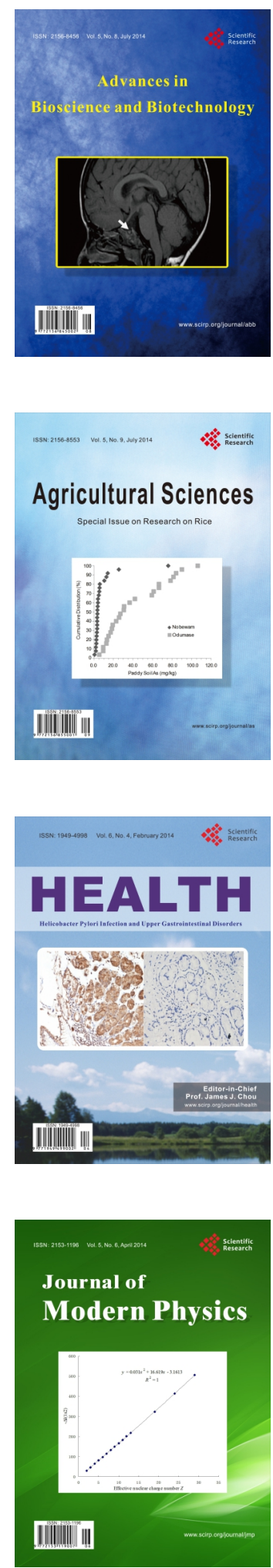
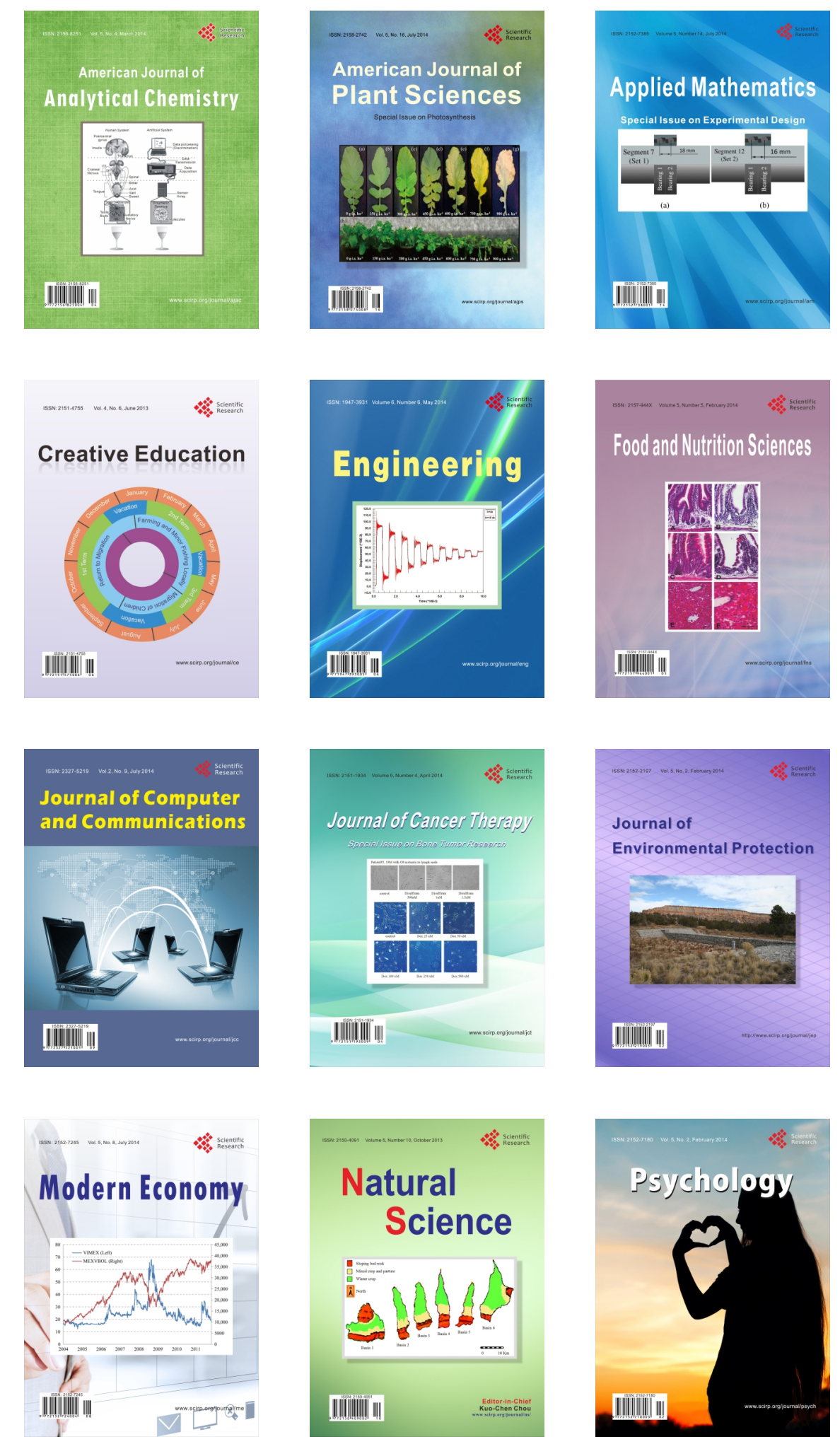